\title{
Toplumsal Cinsiyete Dayalı Meslek Seçimi Ölçeğinin Geliştirilmesi - Kız Öğrenci Formu
}

\section{Development of the "Attitude Towards Gender Based Choice of Profession Scale- Female Form}

\author{
Özlem Haskan AVCI ${ }^{1}$, Mustafa Zahid TOZAR², Y1lmaz HASRET ${ }^{3}$, Seydihan YİĞİT ${ }^{4}$, Ezgi \\ ÖZDEMIR ${ }^{5}$
}

- Geliş Tarihi: 25.03.2018 • Kabul Tarihi: 31.07.2018 • Yayın Tarihi: 01.01.2019

\section{Öz}

$\mathrm{Bu}$ çalışmanın amacı, ortaöğretim düzeyindeki kız öğrencilerin toplumsal cinsiyete dayalı meslek seçimi tutumlarını ölçen bir ölçek geliştirmektir. Çalışma gereği, Ankara'da farklı sosyo-ekonomik düzeydeki liselerde 9-12. sınıfta okuyan ve çalışmaya katılmayı kabul eden kız öğrencilerden veri toplanmıştır. Öncelikle, 259 öğrenciden veri toplanarak pilot uygulama gerçekleştirilmiştir. Ölçeğin geçerlik çalışmaları kapsamında açımlayıcı faktör analizi ve doğrulayıcı faktör analizi yapılmıştır. Açımlayıcı faktör analizi sonuçları Toplumsal Cinsiyete Dayalı Meslek Seçimi Tutum Ölçeğinin (TCDMSTÖ) toplam varyansın \% 60.019'unu açılayan, 24 maddelik, 7 faktörlü bir yapıya sahip olduğunu ortaya koymuştur. Doğrulayıcı faktör analizi sonuçları 7 faktörlü yapıyı desteklemiștir. Ölçeğin güvenirliği iç tutarlık katsayısı ve test tekrar test teknikleri ile değerlendirilmiştir. Ölçeğin iç tutarlık katsayıs1 .853 olarak bulunmuştur. Testin tekrarı yoluyla iki uygulamadan elde edilen veriler arasındaki korelasyon .812 olarak bulunuştur. Çalışma sonucunda, ölçeğin ortaöğretim düzeyindeki kız öğrencilerin toplumsal cinsiyete dayalı meslek seçimi tutumlarını geçerli ve güvenilir olarak ölçebildiği sonucuna varılmıştır.

Anahtar Sözcükler: Toplumsal cinsiyet, meslek seçimi, kadın toplumsal cinsiyet rolü, ölçek

\section{Önerilen Atıf Bilgisi:}

Avc1, Ö.H., Tozar, M.Z., Hasret, Y., Yiğit, S. ve Özdemir, E.(2019). Toplumsal cinsiyete dayalı meslek seçimi ölçeğinin geliştirilmesi-kız öğrenci formu. Pamukkale Üniversitesi Eğitim Fakültesi Dergisi, 45, 252-266.

\footnotetext{
${ }^{1}$ Dr.Öğr.Üyesi, Hacettepe Üniversitesi, Eğitim Fakültesi, Eğitim Bilimleri Bölümü, Psikolojik Danışma ve Rehberlik Anabilim Dal1, Ankara. ORCID: 0000-0003-4903-6584, haskan@ hacettepe.edu.tr

2 Arş.Gör., İstanbul Medeniyet Üniversitesi, Eğitim Bilimleri Fakültesi, Eğitim Bilimleri Bölümü, Psikolojik Danışma ve Rehberlik Anabilim Dalı, İstanbul. ORCID: 0000-0002-1466-9608, zahid.tozar@medeniyet.edu.tr

3 Arş.Gör., Pamukkale Üniversitesi, Eğitim Fakültesi, Eğitim Bilimleri Bölümü, Psikolojik Danışma ve Rehberlik Anabilim Dal1, Denizli. ORCID: 0000-0003-2945-5247, yilmazhasret@ pau.edu.tr

${ }^{4}$ Uzm. Psik. Dan., Milli Eğitim Bakanlığı, Ankara. ORCìD: 0000-0002-8346-5430, seydihanygt@gmail.com

${ }^{5}$ Psik. Dan., Özel Uğur Okulları, Ankara. ORCID: 0000-0002-7341-7507, e.oozdemir@ gmail.com
} 


\begin{abstract}
The purpose of this study is to develop a scale to measure attitude towards gender based choice of profession for female high school students. The subjects of this study were girls from 9 and 12 high schools which are from different socio-economic levels. In this study, firstly data collected from 259 students' entered into SPSS. Explanatory and confirmatory factor analysis was used in order to identify the validity of Attitude Towards Gender Based Choice of Profession Scale (ATGBCPS). The results of explanatory factor analysis showed that the construct of this scale has 24 items and 7 factors and it explain $60.019 \%$ of total variance. Confirmatory factor analysis supported these results. The reliability of the scale was tested with Cronbach-Alpha coefficient and split-half method by applying the scale to 174 students. Cronbach-Alpha reliability coefficient was found as .853 and the test-retest reliability coefficient found as .812 . The findings of the study shows that ATGBCPS is able to measure attitude towards gender based choice of profession for female high school students.

Keywords: Gender, choice of profession, female gender role, scale
\end{abstract}

\title{
Giriş
}

Tarih boyunca kadın ve erkeklerin iş ortamındaki rollerine cinsiyete bağlı olarak farklı anlamlar yüklenmiştir. Bu durum sadece iş ortamında değil aynı zamanda toplumda pek çok alanda cinsiyet ayrımcılığına, sosyal olarak eşitsizliğe ve güç farklılıklarına yol açmaktadır (Frader, 2004). Özellikle sanayi devriminden sonra kadınların ekonomik faaliyetlerde ve iş ortamındaki etkinlikleri artsa da bu artış iş ortamında ve meslek seçiminde cinsiyetler arasındaki dengeyi sağlayamamıştır (Parlaktuna, 2010). Doğum kontrol yöntemlerinin gelişmesi, sanayi devriminin etkisi gibi gelişmelere rağmen, kadınlar için uygun görülen işlerin nitelikleri, toplumun kadın cinsiyetine yüklediği görev ve misyonun çerçevesini aşamamaktadır (Pilcher ve Whelehan, 2004). Dolayısıyla, toplumsal hayatta kadına atfedilen edilgin rollerin kadınları büyük ölçüde sınırlandırdığı söylenebilir. Correll'a (2001) göre bu gibi ayrımcı tutumlar özellikle kadınlar için var olan iş olanaklarını kısıtlamaktadır. Bu durum her iki cinsiyet için de meslek seçimi sırasında görünürde gönüllü bir tavırla geleneksel toplumsal cinsiyet rollerine uygun mesleklere yönelme durumunu ortaya çıkarmaktadır. Bu durum cam tavan etkisini çağrıştırmaktadır. Genel olarak cam tavan kadınların üst yönetim kademelerine gelmelerini engelleyen görünmez yapay engeller olarak tarif edilmektedir (Weiler ve Bernasek, 2001).

Toplumsal cinsiyet rollerine uygun mesleki yönelimde bulunma durumu hem Türkiye'nin hem dünyanın güncel bir sorunu gibi görünmektedir. Örneğin, Avrupa'da kız öğrenciler erkek öğrencilere göre; güzellik, moda, tekstil, eğitim, kültür, psikoloji, toplum ve dil gibi alanlara daha çok yönelmekte ve yönlendirilmektedir. Erkek öğrenciler ise kız öğrencilere göre; teknoloji, fen bilimleri, mekanik gibi alanlara daha çok yönelmekte ve yönlendirilmektedir (Deutsche Gesselschaft für Internationale Zusammenarbeit, 2012). Ancak batıda kadınların az temsil edildiği mesleklerde kendilerine yer bulmaları için onları cesaretlendiren, destekleyen kurumlar bulunmaktadır. Örneğin, IEEE (Institute of Electrical and Electronics Engineer) Women In Engineering, dünya çapında kadınlara mühendislik ve bilim alanlarında ilham verme ve bu alanda kariyer yapmaları konusunda cesaretlendirme amacını taşıyan bir kuruluştur. Women In Project Management (WIPM), Avrupa'da kadınlara proje yöneticiliği konusunda uygun ortamı sağlama amaçlı yapılan bir çalışmadır. Buradan hareketle hem kadınların hem erkeklerin çocukluktan itibaren kendilerine verilen toplumsal cinsiyet algılarından sıyrılarak potansiyellerini ortaya koymaları amaçlanmaktadır. Bununla birlikte kadın erkek eşitsizliğinin araştırılması için de birçok komisyon kurulmuştur. Bunlarda birisi The Equal Opportunities Commission (EOC)'dur. EOC, iş ortamında erkek ve kadın çalışanlar arasında yapılan ayrımcılık konusunu araştırmıştır. Bu araştırmanın sonucunda, iş ortamında kadın ve erkekler arasında yapılan ayrımcılığın işgücünü ve üretkenliği sınırladığı, aynı zamanda kariyer 
seçeneklerinin cinsiyete göre değişmesine neden olduğu ortaya çıkmıştır. Hatta modern çıraklık eğitiminde dahi kadınların ve erkeklerin birbirlerinden farklı meslekler seçtikleri, erkeklerin daha çok teknik konulara yönelirken kadınların çocuk bakımı, saç tasarımı, vb. meslek gruplarına yöneldikleri gözlemlenmiştir (The Equal Opportunities Commission [EOC], 2005).

Türkiye'nin 128 ülke arasında cinsiyet ayrımı endeksine göre 123. sirada olması ve bu oran ile de OECD ülkeleri arasında da en düşük kadın istihdam eden ülke konumunda bulunması kız çocukları için olumsuz bir tablo çizmektedir. Yine de toplumsal cinsiyet eşitliği temelli çalışmaların son yıllarda arttığı görülmektedir. Aile ve Sosyal Politikalar Genel Müdürlügü bünyesinde yer alan Kadının Statüsü Genel Müdürlüğü ilk olarak 2008-2013 yılı Toplumsal Cinsiyet Eşitliği Ulusal Eylem Planı yayınlamıştır. Sonrasında ise 2014-2019 yılı planını hazırlamak amacıyla güncelleme çalışmaları için çalıştaylar düzenlenmiştir. $\mathrm{Bu}$ güncelleme başlığında kadınların sağlık, eğitim, ekonomi, yoksulluk, çevre, medya, yetki ve karar alma mekanizmalarında yaşadıkları sorunlar ele alınmış ve cinsiyet eşitliğinin geliştirilmesine yönelik atılacak adımlar üzerinde durulmuştur. Çalışma ve Sosyal Güvenlik Bakanlığı ise ilk defa "Kadın İstihdamı Eylem Planı (2016-2018)" hazırlıklarını yapmışlardır. $\mathrm{Bu}$ eylem planında kadının işgücü piyasasına daha etkin katılmasına, iyi işlerde çalışmalarına ve toplumsal cinsiyet eşitliği gibi konulara önem verildiği görülmektedir.

Gıda, Tarım ve Hayvancılık Bakanlığı ise 2012 yılında "Kırsal Alanda Kadının Güçlendirilmesi Ulusal Eylem Planı" yayımlamışlardır. Bu eylem planıyla kadınların da tarımsal üretimde sorumluluk almaları ve üretime katılmaları ve cinsiyet eşitsizliğinin azaltılması hedeflenmektedir. Benzer şekilde, Milli Eğitim Bakanlığı tarafından düzenlenen ETCEP (Eğitimde Toplumsal Cinsiyet Eşitliğinin Sağlanması Projesi) eğitim ortamlarında ve kamuoyunda toplumsal cinsiyet eşitliği kavramının anlaşılmasını, yaygınlaşmasını ve özellikle eğitim ortamlarında toplumsal cinsiyet eşitliğinin dikkate alınarak uygulamalar yapılmasını amaçlamaktadır. (MEB, 2016). Bakanlıklar düzeyinde toplumsal cinsiyet eşitliğinin sağlanmasına ve bilhassa kadınların toplumsal cinsiyet kaynaklı dezavantajlı konumlarının azaltılmasına yönelik önemli girişimlerin olduğu görülmektedir. Bu gibi çalışmaların dışında, özel kuruluşların da toplumsal cinsiyet eşitliğini destekleyen sosyal sorumluluk projeleri söz konusudur. Örneğin, Ford Otosan ve Türk PDR Derneği işbirliği ile yürütülen "Bal Arıları Mühendis Oluyor" projesi, kız öğrencilerin mühendis olmalarını teşvik etmek amacıyla, ülke çapında öğrenci, öğretmen ve velilere yönelik eğitim sağlamaktadır.

Bunların yanı sıra, öncülüğünü Ankara, ODTÜ, Hacettepe, Ege ve Dokuz Eylül Üniversiteleri’nin yaptığı ve son yıllarda diğer üniversitelerde de kurulduğu görülen Kadın Sorunları ve Toplumsal Cinsiyet Araştırma Merkezleri, Kadın Çalışmaları Anabilim Dalları ve lisansüstü programları toplumsal cinsiyetle ilgili araştırmaların artmasına ivme kazandırmıştır. Ayrıca, YÖK tarafindan farklı üniversitelerinden kadın akademisyenler ve sivil toplum kuruluşlarının kadın temsilcilerinden oluşan katılımcılar ile "Toplumsal Cinsiyet Eşitliğine Duyarlı Üniversite Çalıştayı" düzenlenmiş olması da önemli bir gelişme olarak değerlendirilmektedir.

$\mathrm{Bu}$ gibi gelişmelerin ve toplumsal cinsiyet eşitliğine yönelen dikkatin artıyor olması özellikle kız öğrenciler için umut vericidir. Meslek seçimi bireylerin tüm yaşamlarını etkileyebildiği için, bireylerin ilgi ve yetenekleri doğrultusunda meslek seçmeleri konusunda destekleyici yaklaşımlar önem kazanmaktadır. Kız öğrencilerin meslek seçiminde toplumsal 
cinsiyete dayalı tutumlarının olup olmadığı belirlenebilirse daha sağlıklı yönlendirmeler yapılabilir. Toplumsal cinsiyet, yalnızca meslek seçim sürecini değil, genel olarak bireylerin kariyerlerini de etkileyen bir olgu olarak karşımıza çıkmaktadır. Kişinin kariyer sürecinde karşılaştı̆g engellerle başa çıkabilme kapasitesi olarak tanımlanmakta olan kariyer uyumluluğu ile toplumsal cinsiyet algısı arasında pozitif yönde ve anlamlı ilişki bulunduğunu gösteren araştırmalar bulunmaktadır (Siyez ve Belkıs, 2016).

Çetin Gündüz, Tarhan ve Kılıç’a (2015) göre, okul öncesi dönemden itibaren başlayan meslek seçimi sürecinde çocuklar aile üyelerinin, yakın çevrelerinde yaşayan sevdikleri büyüklerin, öğretmenlerinin, arkadaşlarının, izledikleri filmlerdeki kahramanların, medyada öne çıkan ünlü kişilerin etkisinde kalarak meslekleri araştırmaya ve mesleklerin kendilerine uygunluğunu test etmeye başlarlar. $\mathrm{Bu}$ süreci etkileyen faktörler arasında bireyin ilgileri, yetenekleri ve mesleki değerleri, anne-baba ve öğretmenlerin görüşleri, mesleklere atfedilen toplumsal değerler, bireye sunulan eğitim olanakları, okul başarısı ve toplumdaki istihdam politikaları bulunmaktadır. Tüm bu faktörleri etkileyen temel faktörün ise toplumsal cinsiyet olduğu düşünülmektedir (Çetin Gündüz, Tarhan ve Kılıç, 2015). Gönel, Kaplan, Üçer ve Orhan (2012) tarafından Yıldız Teknik Üniversitesi'nde geniş bir örneklemle yürütülen bir araştırmadan elde edilen bulgular, ailelerin evlatlarına meslek seçimleri konusunda toplumsal cinsiyet normları temelli müdahalelerinin olabildiği, aileleri tarafından zaten kendilerine uygun görülen bir meslek/alanda eğitim görme tercihinde bulunan öğrencilere müdahale edilmiyor olabileceği şeklinde yorumlanmıştır.

Literatürde toplumsal cinsiyet kalıp yargılarına veya meslek seçimi tutumlarına yönelik ayrı ölçme araçları bulunmakla birlikte, lise öğrencileri için bu iki kavramı birlikte ele alan bir ölçme aracına rastlanmamıştır. Çetin Gündüz, Tarhan ve Kılıç'ın (2015), ilkokul öğrencilerine yönelik olarak geliştirdikleri "Toplumsal Cinsiyete Dayalı Meslek Seçimlerine Yönelik Tutum Ölçeği” dışında, konuyla ilgili bir ölçme aracına rastlanmamıştır. Özellikle orta öğretim döneminin, yükseköğretime geçiş sınavı öncesinde, yöneltme ve yerleştirme hizmetinin önem kazandığ 1 , meslek seçiminin en kritik hale geldiği dönem olması bakımından, lise öğrencilerine yönelik bir ölçek geliştirilmesi önemli bulunmuştur. Uluslararası literatürde meslek seçimi ve toplumsal cinsiyeti bir arada ele alan madde yazımına yönelik çalışmalar olduğu gibi (McQuaid ve Bond, 2004;), mesleklere yönelik tutumu ve toplumsal cinsiyeti ayrı ayrı ölçmeyi ve sonuçları bir arada yorumlamayı hedefleyen çalışmalar da (Golden, 2011; Callahan, 2015) bulunmaktadır. Toplumsal cinsiyet konusunun meslek seçiminde oldukça önemli bir değişken olduğu tahmin edilmektedir. Dolayısıyla bu çalışmada, ortaöğretim düzeyindeki kız öğrencilere yönelik, toplumsal cinsiyet ve meslek seçimini bir arada ele alan likert tipi bir tutum ölçeği geliştirilmesi hedeflenmiştir.

\section{Yöntem}

\section{Çalışma Grubu}

Bu çalışma kapsamında Ankara ili merkez ilçelerinde farklı sosyo ekonomik düzeyde bulunan 3 lisede 9 ila 12. sınıfta öğrenim gören 453 öğrenciye ulaşılmıştır. Ölçek maddeleri henüz meslek seçmemiş kişilere yönelik olduğundan ve belirli bir mesleki seçime yönelmeyi ifade ettiğinden, meslek lisesine devam eden öğrenciler ölçek geliştirme çalışmasına dahil edilmemiştir. Çalışmaya katılan öğrencilere ait bilgiler ise Tablo 1'de sunulmuştur. 
Tablo 1. Çalışma Grubunun Okul Türü ve Sınıf Düzeyine Göre Dağılımı

\begin{tabular}{lll}
\hline Sinıf Düzeyi & Özel Anadolu Lisesi & Anadolu Lisesi \\
\hline 9. Sinıf & 48 & 84 \\
10. Sinıf & 34 & 83 \\
11. Sinıf & 25 & 145 \\
12. Sinıf & 21 & 13 \\
Toplam & 128 & 325 \\
\hline
\end{tabular}

\section{Veri Toplama}

Ölçek geliştirme süreci doğrultusunda, hazırlanan ölçeğin deneme ve pilot uygulamalarını gerçekleştirebilmek için farklı liselerden kız öğrencilere ulaşılmıştır. Verilerin toplanmasında uygulama yapılmasına onay veren kurumlara ulaşma kolaylığı bakımından uygun örnekleme yöntemi tercih edilmiştir. Sosyal bilimlerde yaygın kullanılan örnekleme türlerinden biri olan uygun örneklemede, araştırmacılar katılımcıları ulaşması kolay, araştırma için uygun ve gönüllü bireylerden seçmektedir (Gravetter ve Forzano, 2012).

\section{İşlem}

Toplumsal cinsiyete dayalı meslek seçimi tutumu değişkenini ölçmeye yönelik likert tipi bir ölçek geliştirebilmek için öncelikle ilgili literatür incelenmiştir. Kadın toplumsal cinsiyet rolü ve bu rolle ilgili kültürel beklentiler; meslek seçim sürecine yansımaları dikate alınarak maddeler yazılmıştır. Araştırmacılar tarafından 5 tanesi ters puanlanmaküzere 45 maddelik bir madde havuzu oluşturulmuştur. Madde havuzunda, "Kadınların seçmesi gereken meslekler, erkeklerinkinden farklıdır", "Kadınlar toplumun kadına uygun gördüğ̈̈ meslekleri tercih etmelidir" ve "Güç ve otorite gerektiren işler kadınlar için uygun değildir." gibi, toplumsal cinsiyete dayalı meslek seçimine yönelik tutum ifade eden maddeler yer almaktadır.

Oluşturulan madde havuzu PDR alanından olup toplumsal cinsiyet alanında çalışmaları olan 2 uzmanın görüşüne sunulmuştur. Uzmanlardan maddeleri "uygun”, "düzeltilmeli”, "uygun değil" biçiminde derecelendirmeleri istenmiştir. Görüşüne başvurulan uzmanların, \% 90 ve üzeri oranda uygun buldukları maddeler (Büyüköztürk, 2010) ölçeğe olduğu gibi alınmış; değiştirilmesi önerilen maddeler üzerinde gerekli değişiklikler yapılmıştır.

$\mathrm{Bu}$ hali ile deneme formu bir sınıfta 34 öğrenciye uygulanmıştır. Deneme uygulamasında anlaşılmayan, açık olmayan maddeler olduğu belirlenmiş ve bu maddeler yeniden düzenlenmiştir. Düzenlenmiş hali ile uygulama formu 259 öğrenciye uygulanmıştır. Elde edilen veriler açımlayıcı faktör analizine tabi tutulmuştur. Faktör analizi doğrultusunda birinci faktörde faktör yük değerleri .30'dan düşük çıkan, faktör yük değerleri farklı faktörlerde birbirine yakın olan, ayırt ediciliği düşük olan ve diğer ölçek maddeleri ile düşük korelasyon veren 21 madde ölçekten çıkarılmıştır. Faktör analizi sonucunda kalan 24 maddeden oluşan ölçeğin son formu 32 öğrenciye uygulanmış ve elde edilen verilerle test tekrar test güvenirliği 
incelenmiştir. Ölçeğin faktör yapısını doğrulamak için, açımlayıcı faktör analizinden sonra ulaşılan ölçek formu ile doğrulayıcı faktör analizi yapılmıştır.

\section{Verilerin Analizi}

Verilerin analizinde SPSS paket programı kullanılmıştır. Öncelikle, verilerin faktör analizi için uygun olup olmadığı incelenmiştir. KMO değeri .854 olup Bartlett testi .00 düzeyinde anlamlı olduğu için veriler faktör analizi için uygun (Büyüköztürk, 2010) bulunmuştur. Bunun üzerine ölçeğin faktör yapısı ve maddelerin faktör yükleri Açımlayıcı Faktör Analizi ile incelenmiştir. Faktörleştirme tekniği olarak da temel bileşenler analizi (principle compenent analysis, PCA) seçilmiştir. Analizlerde faktörlerin her bir değişken üzerindeki ortak faktör varyansı, maddelerin faktör yükleri, açıklanan varyans oranları incelenmiştir. Faktör yapılarının belirlenmesinde, maddelerin .30 ve üzerinde faktör yük değerlerine sahip olması dikkate alınmıştır. Component Matriks tablosunda birinci faktörde maddelerin faktör yüklerinin .30 ve üzerinde olması ile toplam puanın kullanılabilmesi esas alınmıştır (Büyüköztürk, 2010). Birbiriyle ilişkili maddelerin bir araya gelerek faktör oluşturması ve faktörlerin daha kolay yorumlanabilmesi amaciyla Varimax eksen döndürme tekniği seçilmiştir. İnceleme sonunda birinci faktörde faktör yük değerleri .30'dan düşük çıkan, faktör yük değerleri farklı faktörlerde birbirine yakın olan, ayırt ediciliği düşük olan ve diğer ölçek maddeleri ile düşük korelasyon veren maddeler ölçeklerden çıkarılmıştır. Açımlayıcı faktör analizi sonucunda ortaya çıkan faktör yapısını test etmek için doğrulayıcı faktör analizi (DFA) yapılmıştır. Ölçeğin güvenirliği için Cronbach Alpha katsayılarına ve madde-toplam korelasyonlarına bakılmış; test tekrar test yöntemi ile elde edilen veriler arasındaki korelasyon hesaplanmıştır.

\section{Bulgular}

$\mathrm{Bu}$ bölümde toplumsal cinsiyete dayalı meslek seçimi tutumu değişkenini ölçmeye yönelik olarak geliştirilen ölçeğin faktör analizi sonuçları ele alınmıştır. Tablo 2'de faktör ortak varyansı ve maddelerin 1. Faktördeki yük değerleri sunulmuştur.

Tablo 2'de görüldüğü üzere, faktörlerin her bir değişken üzerindeki ortak faktör varyansı .515 ile .746 arasında değişmektedir. Birbiriyle ilişkili maddelerin bir araya gelerek faktör oluşturması ve faktörlerin daha kolay yorumlanabilmesi amaciyla Varimax eksen döndürme tekniği seçilmiştir. Faktör yük değerleri farklı faktörlerde birbirine yakın olan maddeler ölçekten çıkarılmıştır. Varimax eksen döndürme tekniği sonucunda kalan maddelerin bir araya gelerek oluşturduğu faktörler Tablo 3'te verilmiştir. 
Tablo 2. Faktör Analizi Sonuçları

\begin{tabular}{|c|c|c|c|c|c|c|c|}
\hline Madde & Fak.Ortak & Madde & Faktör1 & Madde & Fak. & Madde & Faktör1 \\
\hline \multirow[t]{2}{*}{ No } & Varyans1 & No & Yük & No & Ortak & No & Yük \\
\hline & & & Değeri & & Varyans1 & & Değeri \\
\hline M4 & ,556 & M22 &, 700 & M24 & ,616 & M17 &, 464 \\
\hline M6 &, 583 & M28 & ,634 & M26 & ,575 & M42 &, 442 \\
\hline M9 & ,604 & M26 & ,632 & M39 & , 496 & M37 &, 434 \\
\hline M12 & ,615 & M12 & ,610 & M10 &, 542 & M35 &, 423 \\
\hline M13 & ,565 & M24 & ,607 & M25 & ,608 & M14 &, 355 \\
\hline M15 & ,746 & M45 &, 586 & M14 & ,765 & M15 &, 447 \\
\hline M17 & ,641 & M6 &, 579 & M42 & , 455 & M10 &, 391 \\
\hline M22 & ,631 & M9 &, 537 & M40 &, 551 & M40 & ,463 \\
\hline M28 & ,624 & M4 &, 533 & M43 & ,690 & M7 & ,368 \\
\hline M34 &, 595 & M13 &, 531 & M7 & ,686 & M25 & ,396 \\
\hline M35 &, 549 & M21 &, 518 & M37 &, 518 & M43 & ,381 \\
\hline M45 & 679 & M34 & ,492 & M21 &, 515 & M39 &, 465 \\
\hline
\end{tabular}

Tablo 3'te görüleceği üzere, ölçekte bulunan 7 faktör birlikte toplam varyansın \% 60.019'unu açıklamaktadır. Birinci faktör tek başına toplam varyansın \% 25.835'ini; ikinci faktör \% 9.914'ünü; üçüncü faktör \% 5.576'sını; dördüncü faktör \% 5.285'ini; beşinci faktör \% 4.764'ünü; altıncı faktör 4.466'sını, 7. Faktör \% 4.180'ini açıklamaktadır. Tablo 2'de de izleneceği gibi, Varimax eksen döndürme tekniği sonrasında, birinci faktörün 5 maddeden; ikinci faktörün 4 maddeden; diğer faktörlerin üçer maddeden oluştuğu görülmektedir. Maddelerin döndürme öncesindeki birinci faktördeki yük değerlerinin .30'un üstünde olmas1; birinci faktörün tek başına açıkladığı varyansın yüksek olması ve çizgi grafiğginde birinci faktörden sonra hızlı bir düşmenin gözlenmesi; ölçeğin genel bir faktöre sahip olduğunu göstermektedir. Buna göre, ölçek toplam puana göre değerlendirilmektedir.

Toplam puanın yüksek olması meslek seçiminde toplumsal cinsiyete dayalı kalıplaşmış tutumların fazla olduğunu göstermektedir. Puanların düşük veya yüksek oluşuna bakılarak, kız öğrencilerin meslek seçiminde toplumsal cinsiyete dayalı bir tutum içinde olup olmadıkları anlaşılabilir. 
Tablo 3. Döndürme Sonrası Yük Değerleri

\begin{tabular}{|c|c|c|c|c|c|c|c|}
\hline Madde No & Faktör 1 & Faktör 2 & Faktör 3 & Faktör 4 & Faktör 5 & Faktör 6 & Faktör 7 \\
\hline M24 &, 722 & & & & & & \\
\hline M26 & ,678 & & & & & & \\
\hline M21 & ,666 & & & & & & \\
\hline M28 & ,631 & &, 363 & & & & \\
\hline M22 & ,580 & &, 310 & & & & \\
\hline M14 & &, 867 & & & & & \\
\hline M15 & &, 842 & & & & & \\
\hline M13 & & ,675 & & & & & \\
\hline M10 & & ,627 & & & & & \\
\hline M45 & & &, 759 & & & & \\
\hline M9 & & &, 731 & & & & \\
\hline M12 & & & ,641 &, 310 & & & \\
\hline M7 & & & & ,785 & & & \\
\hline M6 & & & & ,641 & & & \\
\hline M4 & &, 367 & &, 595 & & & \\
\hline M35 & & & & & ,706 & & \\
\hline M34 & & & & & 697 & & \\
\hline M40 & & &, 318 & & ,635 & & \\
\hline M43 & & & & & &, 791 & \\
\hline M39 & & & & & & 609 & \\
\hline M42 & & & & & & ,469 & \\
\hline M17 & & & & & & & ,634 \\
\hline M25 & & & & &, 327 & &, 532 \\
\hline M37 & & & & & & ,317 &, 445 \\
\hline
\end{tabular}

Açıklanan Varyans: Toplam: \% 60.019

Faktör-1: \% 25.835 Faktör-2: \% 9.914

Faktör-3: \% 5.576

Faktör-4: \% 5.285

Faktör-5: \% 4.764

Faktör-6: $4.466 \quad$ Faktör 7: \%4.180

Açımlayıcı faktör analizi sonucunda ulaşılan faktör yapısını test etmek için doğrulayıcı faktör analizi yapılmıştır. Doğrulayıcı faktör analizi sonucunda ortaya çıkan 7 faktörlük yapının doğrulandığı görülmüştür. Doğrulayıcı faktör analizi ile test edilen model Şekil 1'de verilmiştir. 


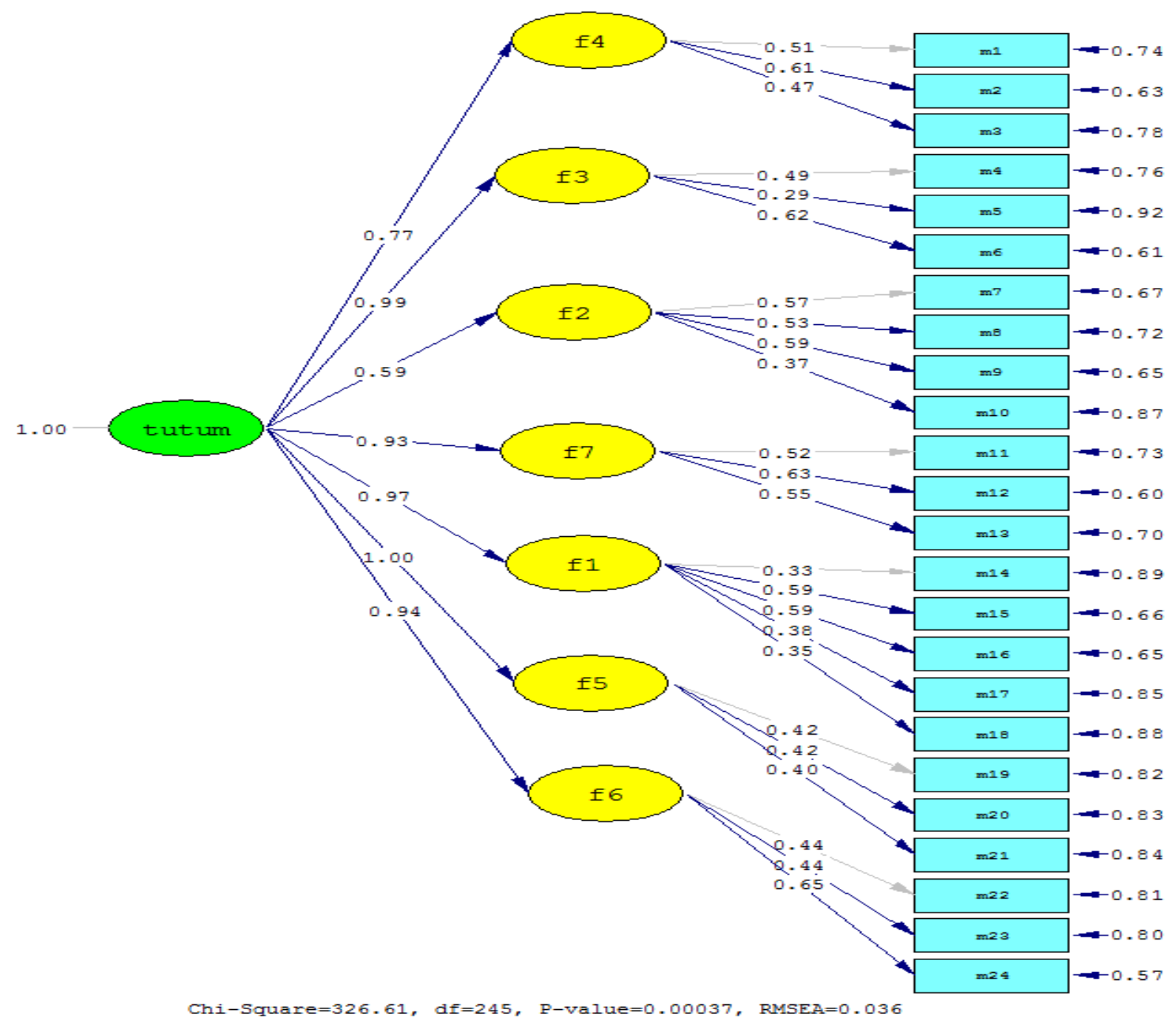

\section{Şekil 1. DFA Sonuçları}

Şimşek (2007)'e göre modelin uygunluk gösterebilmesi için uyum iyiliği kriterleri incelendiğinde, ki-kare ile serbestlik derecesi arasındaki oranın en fazla 3 veya 4 olmasi; RMSEA (Yaklaşık Hataların Ortalama Karekökü/ Root Mean Square Error of Approximitation) ve SRMR(Standartlaştırılmış Artık Ortalamaların Kare Kökü/ Standardized Root Mean Square Residual) değerlerinin .08'in altında olması; GFI(İyilik Uyum İndeksi/Goodness of Fit Index), AGFI (Düzeltilmiş İyilik Uyum İndeksi/Adjusted Goodness of Fit), CFI (Karşılaştırmalı Uyum İndeksi/Comperative Fit Index), IFI (Artan Uyum İndeksi/Incremental Fit Index) değerlerinin ise .90 'ın üzerinde olması beklenmektedir. Açımlayıcı faktör analizinden elde edilen verilere göre yedi boyutlu bir yapı gösteren ölçeğin doğrulayıcı faktör analizi sonuçlarına göre uyum indeksleri $x^{2} / \mathrm{sd}=1.33$ (326.61/245); RMSEA=.036; SRMR=.056; CFI=.97; IFI=.97; GFI=.92; AGFI=.90 olmak üzere belirlenmiştir. Bu değerler literatürde belirtilen değerlerle örtüşmektedir (Şimşek, 2007).

\section{Ölçeğin Güvenirliğgi}

Ölçeğin güvenirliği iki yolla test edilmiştir: Birincisi, iç tutarlık katsayısı incelenmiştir. Cronbach Alpha güvenirlik katsayısı $\alpha=.853$ olarak bulunmuştur. Ölçeğe ilişkin güvenirlik analizi sonuçları tablo 4 'te sunulmuştur. 
Tablo 4. Ölçeğin Güvenirlik Analizine İlişkin Sonuçlar

\begin{tabular}{|c|c|c|c|c|}
\hline $\begin{array}{l}\text { Madde } \\
\text { No }\end{array}$ & $\begin{array}{l}\text { Madde } \\
\text { Çıkarılırsa } \\
\text { Ortalama }\end{array}$ & $\begin{array}{l}\text { Madde } \\
\text { Çıkarılırsa } \\
\text { Varyans }\end{array}$ & $\begin{array}{l}\text { Madde } \\
\text { Toplam } \\
\text { Korelasyonu }\end{array}$ & $\begin{array}{l}\text { Madde } \\
\text { Çıkarılırsa } \\
\text { Alpha }\end{array}$ \\
\hline M4 & 30,4732 & 37,578 & ,502 & ,844 \\
\hline M6 & 30,7010 & 38,154 &, 510 & ,845 \\
\hline M9 & 30,7705 & 39,150 & ,420 & ,848 \\
\hline M12 & 30,8097 & 39,038 & ,470 & ,847 \\
\hline M13 & 30,2763 & 36,561 &, 523 & ,843 \\
\hline M15 & 29,9680 & 37,005 & ,471 & ,845 \\
\hline M17 & 30,7126 & 38,958 & ,380 & ,849 \\
\hline M22 & 30,7778 & 38,791 & ,582 & ,845 \\
\hline M28 & 30,8088 & 39,148 & ,502 & ,847 \\
\hline M34 & 30,4949 & 37,649 & ,458 & ,846 \\
\hline M35 & 30,4290 & 37,958 & ,377 & ,849 \\
\hline M45 & 30,8362 & 39,520 & ,467 & ,848 \\
\hline M21 & 30,7705 & 39,239 & ,402 & ,848 \\
\hline M24 & 30,7396 & 38,552 & ,492 & ,846 \\
\hline M26 & 30,7667 & 38,629 & ,519 & ,845 \\
\hline M25 & 30,2879 & 37,678 & ,369 &, 850 \\
\hline M14 & 29,9173 & 37,175 & ,388 &, 850 \\
\hline M10 & 30,1451 & 37,516 & ,372 &, 850 \\
\hline M39 & 30,4539 & 37,348 & ,400 & ,849 \\
\hline M42 & 30,6787 & 38,880 & ,356 & ,849 \\
\hline M40 & 30,6624 & 38,532 & ,408 & ,848 \\
\hline M43 & 30,7976 & 39,827 & ,292 &, 851 \\
\hline M37 & 30,5620 & 38,025 & ,350 & ,851 \\
\hline M7 & 30,7242 & 39,441 & ,261 & ,853 \\
\hline
\end{tabular}


Ölçeğin güvenirlik çalışmaları kapsamında ayrıca, test tekrar test yöntemine başvurulmuştur. Faktör analizi sonrasında kalan 24 maddelik form, 32 öğrenciye 2 hafta ara ile uygulanmış ve elde edilen ilk verilerle sonraki veriler arasındaki korelasyon incelenmiştir. Buna göre, iki uygulama verileri arasında .812 değerinde pozitif yönde ve .01 düzeyinde anlamlı bir korelasyon bulunmuştur.

\section{Tartışma ve Sonuç}

$\mathrm{Bu}$ çalışmada, toplumsal cinsiyete dayalı meslek seçimi tutumunu ölçebilen bir ölçek geliştirilmesi amaçlanmıştır. Bu doğrultuda, Toplumsal Cinsiyete Dayalı Meslek Seçimi Tutum Ölçeği Kadın Formu'nun geçerlik ve güvenirlik çalışmaları tanıtılmıştır. Ölçeğin geçerliğini sınamak amacıyla, açımlayıcı ve doğrulayıcı faktör analizi çalışmaları yapılmıştır. Ölçeğin güvenirlik çalışmaları kapsamında ise, iç tutarlık katsayısı incelenmiş ve test tekrar test çalışması yapılmıştır. Geçerlik çalışmaları sonucunda, ölçekte bulunan 7 faktörün birlikte toplam varyansın \% 60.019'unu açıkladığı görülmüştür. Güvenirlik çalışmaları sonucunda Cronbach Alpha güvenirlik katsayısı $\alpha=.853$ olarak bulunmuştur. Ölçek 24 maddeden oluşmaktadır. 3'lü likert tipi bir ölçektir. 1=katılmıyorum, $2=$ kısmen katılıyorum ve $3=$ katıllyorum olmak üzere 3'lü derecelendirilmektedir. Ölçekte 3 reverse (tersinden puanlanan) madde bulunmaktadır. Ölçek toplam puana göre değerlendirilmektedir. Toplam puanın yüksek olması meslek seçiminde toplumsal cinsiyete dayalı kalıplaşmış tutumların fazlalığını işaret etmektedir. Hem bireysel hem de grup halinde uygulanabilen ölçeğin ortalama cevaplandırılma süresi 15 dakikadır.

Toplumsal Cinsiyete Dayalı Meslek Seçimi Tutumu Ölçeği özellikle toplumsal cinsiyet ve mesleki rehberlik alanı ilgili olmak üzere, farklı araştırmalarda kullanılabilir. Uygulamacılar, ölçeği, denek seçimi ya da yapılan uygulamanın etkililiğini test etme gibi farklı amaçlarla kullanabilirler. Geliştirilen ölçek kullanılarak, toplumsal cinsiyetin meslek seçimindeki etkisini temel alan ve farklı değişkenlerle ilişkisini konu edinen çeşitli araştırmalar yürütülebilir.

Toplumun geleneksel değerleri ve bu değerlerin biçimlendirdiği toplumsal cinsiyet temelli işbölümü; kadına verilen roller, kadının hangi işlerde çalışabileceği ve hangi meslekleri seçebileceği konusunda önemli rol oynamaktadır (Parlaktuna, 2010). Genel olarak ataerkil özellikler sergileyen ülkemizde, kız öğrencilerin meslek seçimlerinde toplumsal cinsiyet önyarg1 ve baskısı altında kalmadan, yetenek, ilgi ve değerlerine uygun, gerçekçi bir seçim yapabilmeleri konusu oldukça önemli görülmektedir. Meslek seçiminin erken yaşlardan itibaren edinilen bilgi ve deneyimlerden etkilendiği bir gerçektir. Kız ve erkek çocuklara doğar doğmaz verilmeye başlanan toplumsal cinsiyet mesajları da bu seçimi etkileyebilmektedir. Geleneksel ailelerde kız çocuklarının okutulmaması bir problem iken, yalnızca belirli bir seviyeye kadar okumasına olanak sağlayan, ileriki yaşamında çalışmasını onaylamayan aileler de çoktur. Türkiye'nin kimi kesimlerinde kız çocuk ailenin "namusu" olarak algılandığından, her türlü ev dışı etkinlik namusa yönelik tehdit gibi algılanabilmekte ve engellenmektedir. Daha az geleneksel ailelere doğru gidildikçe bu anlayışın, kız çocuğun öğretmen olması ve yarım gün çalışarak evinin işlerini aksatmaması gibi bir yöne doğru evrildiği görülebilir. Gönel ve diğerleri (2012) tarafından yürütülen araştırmada, erkek öğrencilerin daha kalabalık ailelerden geldiği görülmüş ve kadın öğrencilerin daha yüksek eğitim ve gelir seviyesinden ailelerden geldiği 
vurgulanmıştır. Sadece Türkiye'de değil pek çok gelişmekte olan ülkede düşük gelir düzeyine sahip ailelerde, okutulması gerekiyorsa öncelik erkek çocuklara verildiği de belirtilmektedir.

Toplumsal yaşamın birçok alanında kadına ve erkeğe yüklenen kalıp yargılar, kadınlar aleyhine bir ayrımcılık yaratarak, toplum yaşantısında sıklıkla kadınların ikinci plana atılmalarına ve erkeğe kadından daha fazla değer veren bir eşitsizlik modelinin devam etmesine neden olmaktadır. Bu eşitsizlik modeli özellikle çalışma/fırsat eşitliği, kararlara katılım, seçme özgürlüğü, eğitim ve meslek seçiminde daha fazla göze çarpmaktadır (Zeyneloğlu 2008). Özellikle bir mesleğe geçiş sürecinde bulunan ortaöğretim düzeyindeki kız öğrenciler için cinsiyetlerinden bağımsız meslek seçme şansının verilip verilmediği konusu çok daha belirleyici hale gelmektedir. Correll'a (2001) göre cinsiyete dayalı kültürel inançlar, bireylerin çeşitli mesleklere ilişkin yeterliliklerine yönelik algılarını ve yetenekleri üzerindeki kontrollerini de etkilemektedir. Bu doğrultuda, kız öğrencilerin toplumsal cinsiyete dayalı tutumlarına ilişkin öz farkındalıkları oldukça önemlidir. Zira, toplumsal cinsiyet normları etkisinde hareket eden bir birey, bu durumun farkında olmadığı müddetçe, yeteneklerini ve yeterliğini yanlış yorumlayabilir. Dolayısıyla, öğrencilerin kendi toplumsal cinsiyet temelli meslek seçim tutumlarını bilmelerinin, öz farkındalıklarına ve dolayısıyla meslek seçme süreçlerine katkıda bulunacağı; daha bilinçli seçimler yapmalarına yardımcı olacağı varsayılabilir. Bu bağlamda, bu çalışmada geliştirilen ölçek, kız öğrencilerin meslek seçiminde toplumsal cinsiyetin oynadığ 1 role ve kendi tutumlarına ilişkin farkındalıklarının artırılması amacıyla da kullanılabilir. Bilindiği gibi bireyi tanımaya yönelik ölçme araçlarının temel amacı, bireyin kendisini tanımasıdır.

Kız öğrencilerin, "kadın mesleği” diye nitelenen mesleklerle sınırlı tutulmadan, kendi potansiyellerine uygun meslekleri hayal edebilmeleri, en temelde firsat eşitliği açısından değerlendirilmelidir. Geliştirilen ölçek çalışmasının yanı sıra, bu konuda yapılacak çeşitli önleyici ve iyileştirici çalışmalara ihtiyaç duyulduğu açıktır. Bu bağlamda, politika yapıcıların ülke genelinde toplumsal cinsiyet eşitliği temelli çalışmaları desteklemesi ve yaygınlaştırması önerilebilir. 


\section{Kaynakça}

APM Women in Project Management (2017). İnternet'ten 28 Ocak 2017'de https://www.apm.org.uk/community/women-in-project-management-sig/ adresinden alınmıştır.

Bal Arıları Mühendis Oluyor (2017). İnternet'ten 28 Ocak 2017'de https://www.balarilarimuhendisoluyor.com adresinden alınmıştır.

Büyüköztürk, Ş. (2010). Sosyal bilimler için veri analizi el kitabı. (11. Bask1). Ankara: Pegem Akademi.

Correll, S. J. (2001). Gender and the career choice process: The role of biased self-assessments. American journal of sociology. 106, (6), 1691-1730.

Çetin Gündüz, H. Tarhan, S., Kılıç, Z. (2015). Toplumsal Cinsiyete Dayalı Meslek Seçimlerine Yönelik Tutum Ölçeği Geçerlik ve Güvenirlik Çalışması. Bartın Üniversitesi Eğitim Fakültesi Dergisi, 4 (1): $21-33$

Deutsche Gesselschaft für Internationale Zusammenarbeit. (2012). Girls and boys in the World of professions: Gender component in the "Professional orientation in Serbia" Project. İnternet'ten 28 Ocak 2017'de http://profesionalnaorijentacija.org/wp-content/uploads/2011/12/girls-and-boys-in-theworld-of-professions.pdf adresinden alınmıştır.

Equal Opportunities Commision. (2005). Jobs fort he boys and the girls: Promoting a smart, successful $\begin{array}{lllll}\text { and } & \text { equal } & \text { Scotland. } & \text { Internet'ten } & 28\end{array}$ http://www.parliament.scot/S3 EqualOpportunitiesCommittee/General\%20Documents/EOSGBP03A NNEMEI LE.pdf adresinden alınmıştır.

Frader, L. L. (2004). Gender and labor in World history. In T.A. Meade \& M. E.

Gönel, F., Kaplan, Z., Üçer, E., Orhan, G. (2012). Üniversite Eğitiminde Cinsiyet Ayrımcılığının Kökenleri (Ytü Örneği). Sosyal ve Beşeri Bilimler Dergisi, 4 (2): 111-120

Gravetter, J. F. ve Forzano, L. B. (2012). Research methods for the behavioral sciences (4. Bask1). USA: Linda Schreiber-Ganster.

IEEE Women in Engineering (WIE) (2017). The world's largest technical professional organization for the advancement of technology. İternet'ten 28 Ocak 2017'de http://www.ieee.org/membership_services/membership/women/index.html adresinden alınmıştır.

Kadın Statüsü Genel Müdürlüğü. (2008). Kadına yönelik aile içi şiddetle mücadele projesi: Toplumsal cinsiyet eşitliği.

MEB (Milli Eğitim Bakanlığı), (2016). Eğitimde Toplumsal Cinsiyet Eşitliği Projesi （ETCEP). İnternet'ten 28 Ocak 2017'de http://etcep.meb.gov.tr adresinden alınmıştır.

MEB (2016). ETCEP: Toplumsal cinsiyet eşitliğine duyarlı okul standartları kılavuzu.

Parlaktuna, İ. (2010). Türkiye'de cinsiyete dayalı mesleki ayrımcılığın analizi. Ege Akademik Bakış. 4,(10), 1217-1230.

Pilcher, J. \& Wheelan, I. (2004). 50 key concepts in gender studies. Sage Publications: London.

Siyez, D.M., Belkıs, Ö. (2016). Üniversite Öğrencilerinde Kariyer İyimserliği ve Uyumluluğu ile Toplumsal Cinsiyet Algısı Arasındaki İlişki. Eğitim ve Öğretim Araştırmaları Dergisi, 5 (4): 279285.

Şimşek, Ö. F. (2007). Yapısal eşitlik modellemesine giriş temel ilkeler ve Lisrel uygulamaları. Ankara: Ekinox

Weiler, S ve Bernasek, A. (2001) Dodging the Glass Celiling? Networks and The New Wave of Women Entrepreneurs. The Social Science Journal, 38 (1): 85-103.

Zeyneloğlu, S. (2008). Ankara'da hemşirelik öğrenimi gören üniversite öğrencilerinin toplumsal cinsiyet rollerine ilişkin tutumları. Doktora tezi, Hacettepe Üniversitesi Sağlık Bilimleri Enstitüsü, Ankara. 


\section{Extended Abstract}

\section{Introduction}

The development of birth control methods and industrial revolution have made women participate more in business life. Although socially appropriate professions for women are not able to go out of the frame of gender roles. Consequently the passive roles attributed to women are limiting them. Individuals are directed to appropriate professions for their conventional gender roles or they willingly choose these professions in direction of conventional thoughts they have learnt since pre-school. Hence gender roles effect the choice of profession directly or indirectly.

Based on many projects and researches it can be seen that it is important that women should be able to choose their profession without the vocational expectations of society. The aim of this study is to determine the perception of choosing a profession of women and besides that how strongly affected by the sexist messages of society when they making a decision on their career. Consequently the purpose of this study is to develop a reliable and valid scale can be used in school counselling services and career centre when students are in period of choosing a profession. In this study, it was aimed to develop a scale that can measure the attitude towards gender based choice of profession. Accordingly, the validity and reliability studies of the Attitude Towards Gender Based Choice of Profession Scale- Women Form were presented.

\section{Methodology}

Female students from 9th to 12th grades in 3 high schools has been reached and these high schools are located at different socio-economic levels in the central provinces of Ankara. Convenience sampling has been preferred in terms of being easily accessible to students. In order to develop a Likert type scale to measure the variable of attitudes towards gender based occupational choice, the related literature is examined first. Items were written considering women's gender role, expectations about this role and their reflections in choice of profession process. An item pool was created including 45 items and 5 of them was reverse.

The created item pool was presented to the opinion of 2 experts and necessary changes were made in accordance with the recommendation. After that a trial form was formed and applied to a class of students. It was seen that there are items were incoherent and not clear, consequently these items were rearranged. After this arrangement an implementation form was formed and applied to 259 students. The obtained data was used in explanatory factor analysis. In accordance with the explanatory factor analysis, 10 items were excluded. The reasons of this exclusion were following 4 criteria: if item has factor load value lower than .30 in the first factor, if item has factor load values close to each other in different factors, if item has low distinctiveness and if item has low correlation with other scales. The final form of the scale consisting of 24 items was formed according to extractions and applied to 174 students. The obtained data was used to examine test-retest reliability.

\section{Findings}

In order to test validity of the scale, exploratory factor analysis studies were carried out. Within the context of the reliability studies of the scale, internal consistency coefficient and test-retest was examined. As a result of the validity studies, 7 factors included in the scale together 
explained $60.019 \%$ of the total variance. Factor variance of common factor on each variable was found to vary between .515 and .746 . As a result of the reliability studies, the Cronbach Alpha reliability coefficient was found $\alpha=.853$. As a part of reliability studies, the test-retest method was also applied. After the factor analysis, the remaining 24-item form was applied to 32 students at 2-week intervals and the correlation between the first and the next data was examined. Accordingly, it was found that there is a positive and significant correlation between two data sets $(r=.812, p=.01)$.

\section{Discussion}

After analyses, final form of the scale consisting of 24 items is a 3 point Likert scale. It is rated as 1: I agree, 2: I partly agree, 3: I don't agree. There are 3 reverse items in the scale. The scale is evaluated by total points. Higher points indicates more gender based stereotyped attitudes at choice of profession. Attitude Towards Gender Based Choice of Profession Scale can be used in various researches, especially in the fields of gender and vocational guidance. Practicians can use the scale for different purposes such as subject selection and testing efficiency. By using this developed scale, various researches based on the effect of gender on the choice of profession and related to different variables can be carried out. 